\title{
FOOD ECONOMY DURING AND AFTER THE NEOLITHIC- ENEOLITHIC TRANSITION IN THE CENTRAL BALKANS: CONTEXTUALISING CROPS AND DOMESTIC ANIMALS FROM ENEOLITHIC BUBANJ, SOUTHERN SERBIA
}

\author{
Dragana Filipović \\ Institute for Pre- and Protohistory, Kiel University, Germany \\ Jelena Bulatović \\ Laboratory for Bioarchaeology, Faculty of Philosophy, Belgrade, Serbia \\ Aleksandar Bulatović \\ Institute of Archaeology, Belgrade, Serbia \\ \begin{tabular}{r|r} 
e-mail: drfilipovic12@gmail.com & Original scientific paper \\
Received: 10. 5. 2020. & UDC: 903"636"(497.11) \\
Accepted: 31. 7. 2020. & $903: 63 " 636 "(497.11)$
\end{tabular}

\begin{abstract}
In the central Balkans, the period from the second half of the 5th through the mid-3rd millennium BC is known as the Eneolithic. The earlier part of this period has been described as the transition between the Late Neolithic and Early Eneolithic and the time of transformations - societal, economic and ideological. Prevailing understanding of the archaeological record from this period is that the remarkable shifts in the settlement system reflect disintegration of the Neolithic society. What effect did this have on food economy? This question has not yet been addressed using the direct evidence of food production and consumption from archaeological sites. Although such evidence is scarce, it has in recent years been enlarged through new excavations, including those at the long-lasting site of Bubanj in southern Serbia. This paper combines the archaeobotanical and zooarchaeological datasets from Bubanj and examines the integrated evidence from a broader chronological and geographical perspective using the information from other Eneolithic and, also, Late Neolithic sites in Serbia. A picture of agricultural diversity emerges, perhaps reflecting diachronic changes in the production methods and choices. These may have been driven by the social and ecological factors that led to the cultural transformations during and after the transitional period.
\end{abstract}

Keywords: central Balkans (Serbia), Late Neolithic, Eneolithic, crop husbandry, animal herding, socio-economic change

\section{Introduction}

Periods of cultural transformations, reflecting discontinuity/instability, bring excitement to the researchers; in comparison, periods of continuity/stabil- 
ity may even be regarded as "dull periods of little change" (Tringham and Krstić 1990: 573). The transition from the Late Neolithic to the Early Eneolithic (Early Copper Age) in the central Balkans (c. $4500-4000$ BC) was one such dynamic period that witnessed dramatic changes in the settlement pattern, funerary practice and technology of production of tools and other objects (Tasić 1995; Borić 2015; Bulatović and Milanović 2020; Radivojević et al. in prep.). The end of the Late Neolithic is here taken as marked by the end of the well-known Vinča culture phenomenon in the central Balkans. Most of the elements of material expression of this culture disappeared by c. 4550 cal BC (Borić 2009, 2015; Tasić et al. 2015). Archaeological record shows that, following the abandonment of some sizeable Vinča culture sites, small settlements appeared across the central Balkans, including in locations understood as "marginal lands" from the point of view of crop cultivation technology of the time (Chapman 1990). These new settled areas were located away from the previous Vinča culture sites and often situated on hilltops and similar high ground, for instance on high river terraces (Милановић 2017; Kapuran et al. 2018). The proposed reasons for this process include, inter alia, a reduction in soil fertility, deforestation, climatic deterioration and, consequently, unsustainability of the growing population (Chapman 1982, 1990; Kapuran et al. 2018). The dispersion into agriculturally less favourable areas may have been triggered or facilitated by the adoption of inventions such as plough and wheeled transport (Sherratt 1981). A different factor of change, though likely related to the assumed low resource availability, is seen in the "inability" of Late Neolithic communities to participate in the increasingly complex social networks leading to "the breakdown of the networks themselves" (Tringham 1992: 137). Tringham (1992) highlights several variables that could have caused this social fissioning, including tightening the control of labour pool, increasing power over the circulation of goods and people, and the organisational limits of large, aggregated settlements.

The social fissioning played out as "budding dispersal" of small(er) social groups that seem to have created new networks, while exhibiting similarities in the material culture (Tringham 1992). The similarities are visible in, for example, regional pottery forms and decorative styles. Based on these, cultural complexes/networks of the Early and Middle Eneolithic have been reconstructed, such as Tiszapolgár-Bodrogkeresztúr in the northern Balkans and BubanjSălcuţa-Krivodol (or Bubanj-Hum Ia) in the central Balkans (Гарашанин 1973; Tasić 1995). In addition to the new developments recorded at archaeological sites from these periods, significant presence of elements associated with the preceding Late Neolithic/Vinča culture was also noted, primarily in the areas south of 


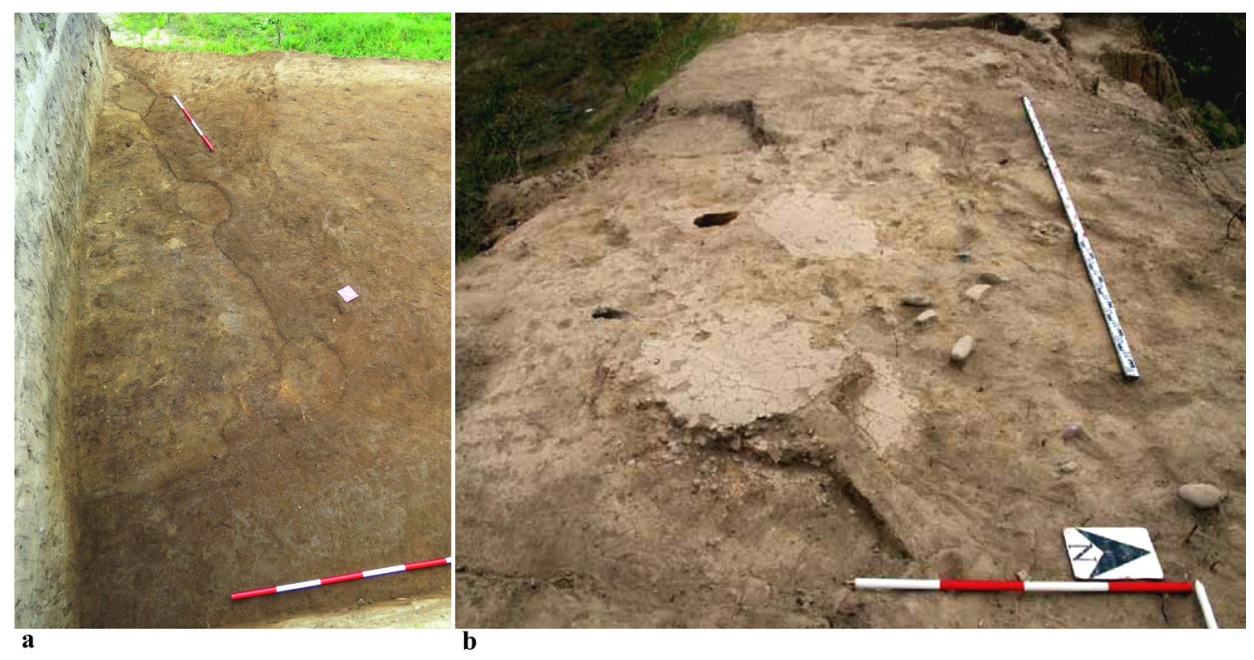

Fig. 1. Bubanj, southern Serbia: examples of preserved house floor made of compacted earth. In the photo on the left, outlines of the floor and the locations of postholes are indicated

Сл. 1. Бубањ, јужна Србија: примери очуваних подница од набијене земље. На левој слици су означене контуре пода и позиције јама за стубове

the Danube, indicating a degree of continuity in material culture. For instance, wattle-and-daub walls and earth-beaten floors known from Neolithic buildings are features of Eneolithic structures (e.g. Гарашанин 1973; Forenbaher 1994; see Fig. 1). On the other hand, previously undetected architectural elements, such as house floors reinforced by river pebbles and stone slabs at some sites in central and southern Serbia (Fig. 2; Томић 1988), speak to new developments.

The available data from the central Balkans are insufficient to allow reconstruction of the size of Eneolithic houses, their number per settlement and the settlement layout. To the north, in the Carpathian Basin, Eneolithic houses and settlements were small and short-lived in contrast to the extensive flat or tell-type settlements composed of large structures that characterised the preceding, Neolithic period (e.g. Parkinson et al. 2004; Link 2009). For the Carpathian Basin too, a far-reaching social change has been postulated during the transition from the Late Neolithic to the Early Copper Age, which seems to have entailed "relaxation" of the social boundaries and relations in response to possible social tensions (Parkinson 2006). In the central Balkans, Eneolithic sites are generally short-lived, at least based on the number of successive occupation layers, since the absolute chronology is lacking in the majority of cases (e.g. Зотовић 1988; Kapuran et al. 2018). The site of Bubanj, however, is one of few known exceptions, as it has been occupied through all the phases of the Eneolithic; the 


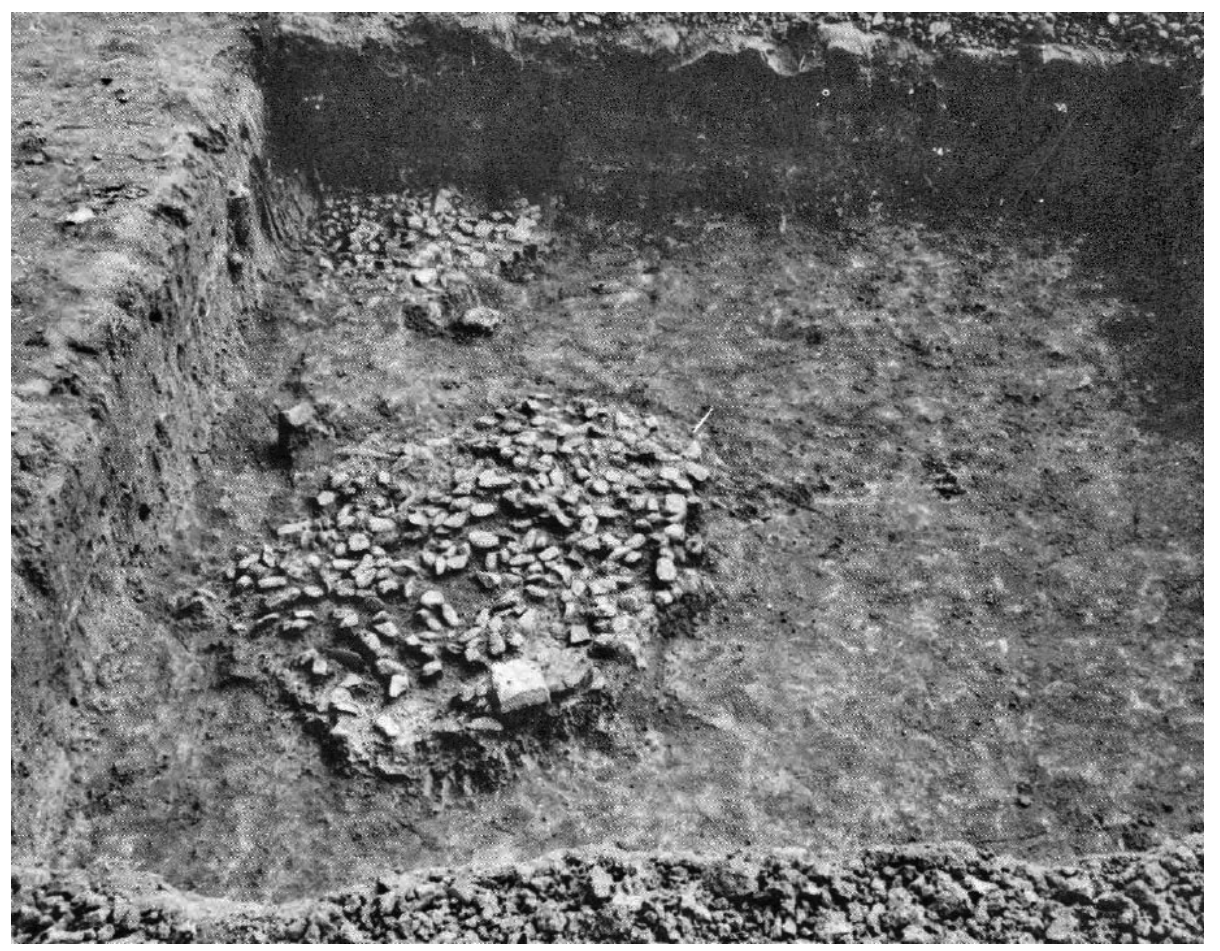

Fig. 2. Makrešani, central Serbia: structure foundation made of river pebbles and stone slabs (after Томић 1988)

Сл. 2. Макрешани, централна Србија: супструкција пода формирана од речних облутака и камених плоча (према Томић 1988)

settlement lasted for at least a millennium, from c. 4400 to $3400 / 3100$ cal BC (Bulatović and Milanović 2020: Table 16).

The evidence of Eneolithic plant and animal economy in the central Balkans is modest. This is because zooarchaeological and archaeobotanical analyses have been conducted for only a handful of sites (Fig. 3) and the assemblages recovered are small in comparison to those from Late Neolithic sites (e.g. Bulatović 2018, 2020; Filipović 2020). Nevertheless, when the data from all of the analysed sites are combined, they allow for some trends and patterns to be discerned in the representation of different taxa across the region. Moreover, they enable a comparison between the Eneolithic and the evidence from the Late Neolithic or Vinča culture period, thus offering a basis for identification of dis-/continuities in the crop and animal husbandry across the Late Neolithic-Eneolithic transition. This is what the present paper is concerned with. The resulting observations facilitate wider geographical and chronological contextualisation of the information gleaned from Bubanj. 


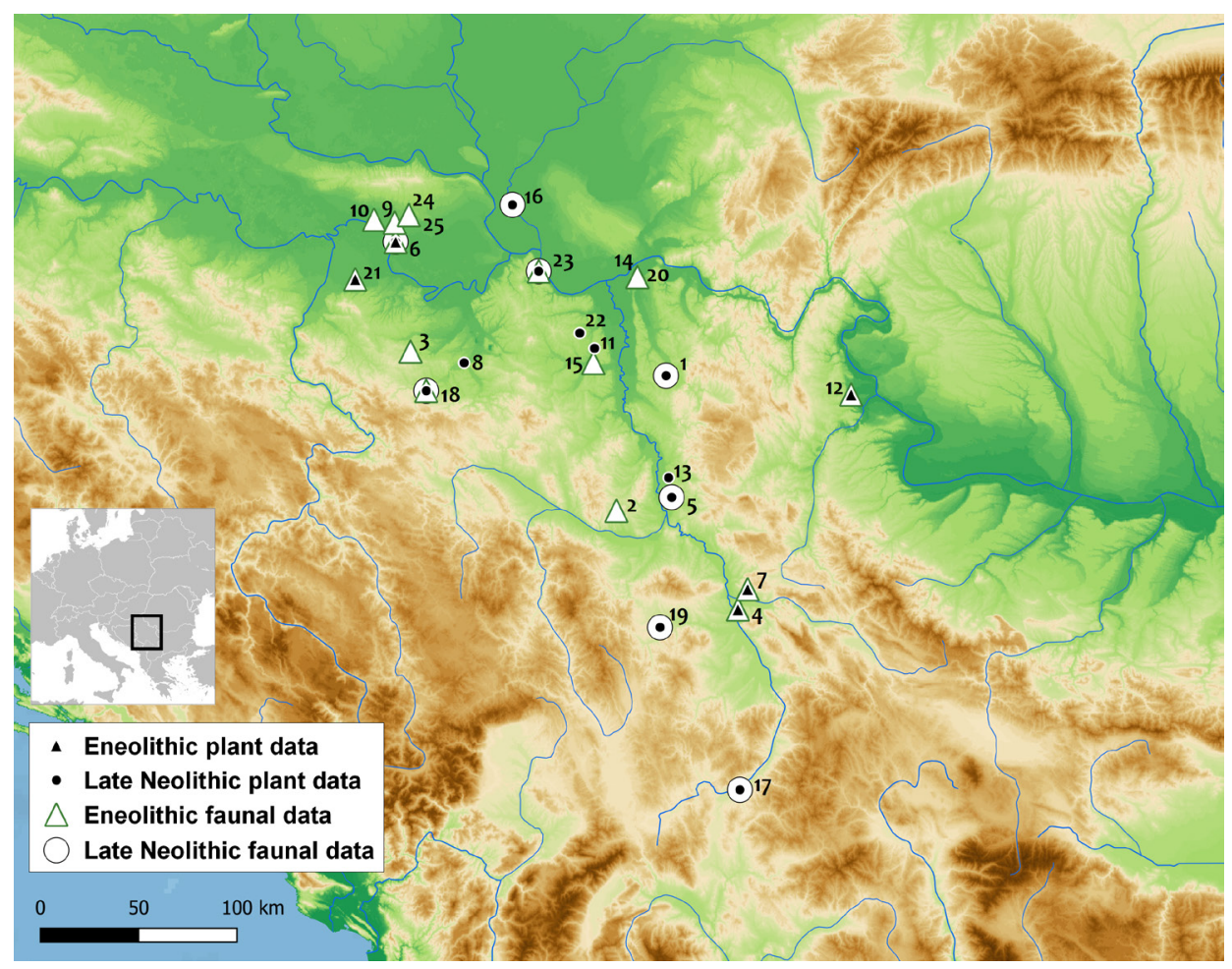

Fig. 3. Location of the Late Neolithic and Eneolithic sites in Serbia from which faunal and/or archaeobotanical assemblages have been analysed: 1. Belovode 2. Blagotin 3. Bodnjik 4. Bubanj 5. Drenovac 6. Gomolava 7. Humska Čuka 8. Jaričište 1-Mali Borak 9. Kudoš-Šašinci 10. Livade-Sremska Mitrovica 11. Medvednjak 12. Mokranjske

Stene 13. Motel-Slatina 14. Nad Klepečkom 15. Novačka Ćuprija 16. Opovo 17. Pavlovac-Gumnište 18. Petnica 19. Pločnik 20. Rit 21. Šanac-Izba 22. Selevac 23. Vinča-Belo Brdo 24. Žirovac-Ruma 25. Zlatara-Ruma

Сл. 3. Положај каснонеолитских и енеолитских локалитета у Србији са којих су анализирани остаци биљака и/или животиња: 1. Беловоде 2. Благотин 3. Бодњик 4. Бубањ 5. Дреновац 6. Гомолава 7. Хумска Чука 8. Јаричиште 1 - Мали Борак 9.

Кудош-Шашинци 10. Ливаде - Сремска Митровица 11. Медведњак

12. Мокрањске стене 13. Мотел - Слатина 14. Над Клепечком 15. Новачка Ћуприја 16. Опово 17. Павловац-Гумниште 18. Петница 19. Плочник 20. Рит 21. ШанацИзба 22. Селевац 23. Винча - Бело Брдо 24. Жировац-Рума 25. Златара-Рума (map-base / основа карте (C) OpenStreetMap contributors; figure created using / карта креирана коришћењем QGIS 3.10.5 - A Coruña (https://qgis.org))

\section{The Eneolithic settlement at Bubanj, southern Serbia}

Bubanj is a multi-period site that, as a result, has the shape of a mound with up to $3.5 \mathrm{~m}$ thick cultural layer (Fig. 4). The major portion of the cultural de- 


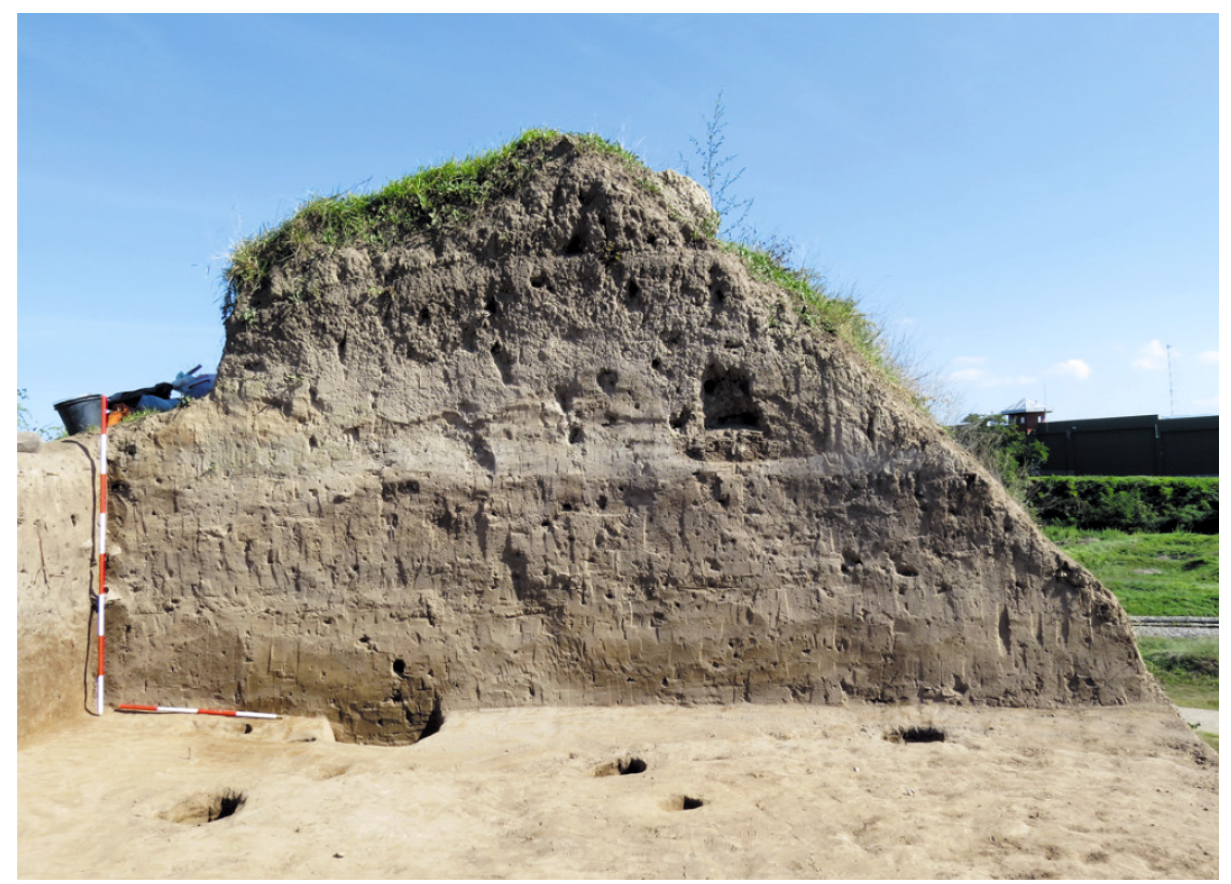

Fig. 4. Bubanj, southern Serbia: section through the mound from the most recent excavations

Сл. 4. Бубањ, јужна Србија: профил кроз тел у сонди отвореној током нових ископавања

posit is attributed to the Eneolithic period, which is here represented by three successive settlements - from the Early, Middle and Late Eneolithic, each comprising two or more occupation phases (Bulatović and Milanović 2020). Recently, a programme of radiocarbon dating has been conducted, producing $18{ }^{14} \mathrm{C}$ dates for the sequence considered here (Vander Linden and Bulatović 2020; Bulatović et al. 2020). With this, solid chronological frame of the Eneolithic occupation of Bubanj has been established (Table 1).

Only the early excavations at Bubanj, i.e. those conducted in the 1930s and 1950s, had the privilege to observe and investigate the c. 5 ha area over which the site likely extended. After the 1958 field campaign, erosion and road construction works destroyed all but c. $200 \mathrm{~m}^{2}$ of the site's extent. This remaining portion was investigated in seasons 2008-2014, during which faunal remains and flotation samples were collected.

The site is located on a low terrace (198 m asl) on the left bank of the Nišava river, several kilometres east of the confluence of the Nišava and the Južna Morava (South Morava) rivers in southern Serbia (Fig. 5). The low ridge 


\begin{tabular}{|l|l|l|c|}
\hline \multicolumn{1}{|c|}{ Period / Период } & $\begin{array}{c}\text { Time-span based on AMS-dates } \\
\text { (саІ ВС) / Дужина периода на } \\
\text { основу радиокарбонских } \\
\text { датума (број датума) }\end{array}$ & Cultural attribution / Културна атрибуција & $\begin{array}{c}\text { Number of } \\
\text { оссupation horizons I } \\
\text { Број насеобинских } \\
\text { хоризоната }\end{array}$ \\
\hline Early Eneolithic / Рани енеолит & $4389-3800$ cal BC (6 dates) & Bubanj-Hum la (Bubanj-Sălcuța-Krivodol complex) & 3 \\
\hline Middle Eneolithic / Средњи енеолит & $3511-3227$ cal BC (5 dates) & Cernavodă III-Boleráz-Baden complex & 2 \\
\hline Late Eneolithic / Касни енеолит & $3341-2943$ cal BC (7 dates) & Coțofeni-Kostolac culture & 3 \\
\hline
\end{tabular}

Table 1. Phases of Eneolithic occupation at Bubanj, their duration based on the absolute dates and the cultural attribution of settlement horizons based on the characteristics of pottery

Табела 1. Енеолитски слој насељавања на Бубњу: фазе, период (на основу апсолутних датума) и културна детерминација (на основу карактеристика керамике)

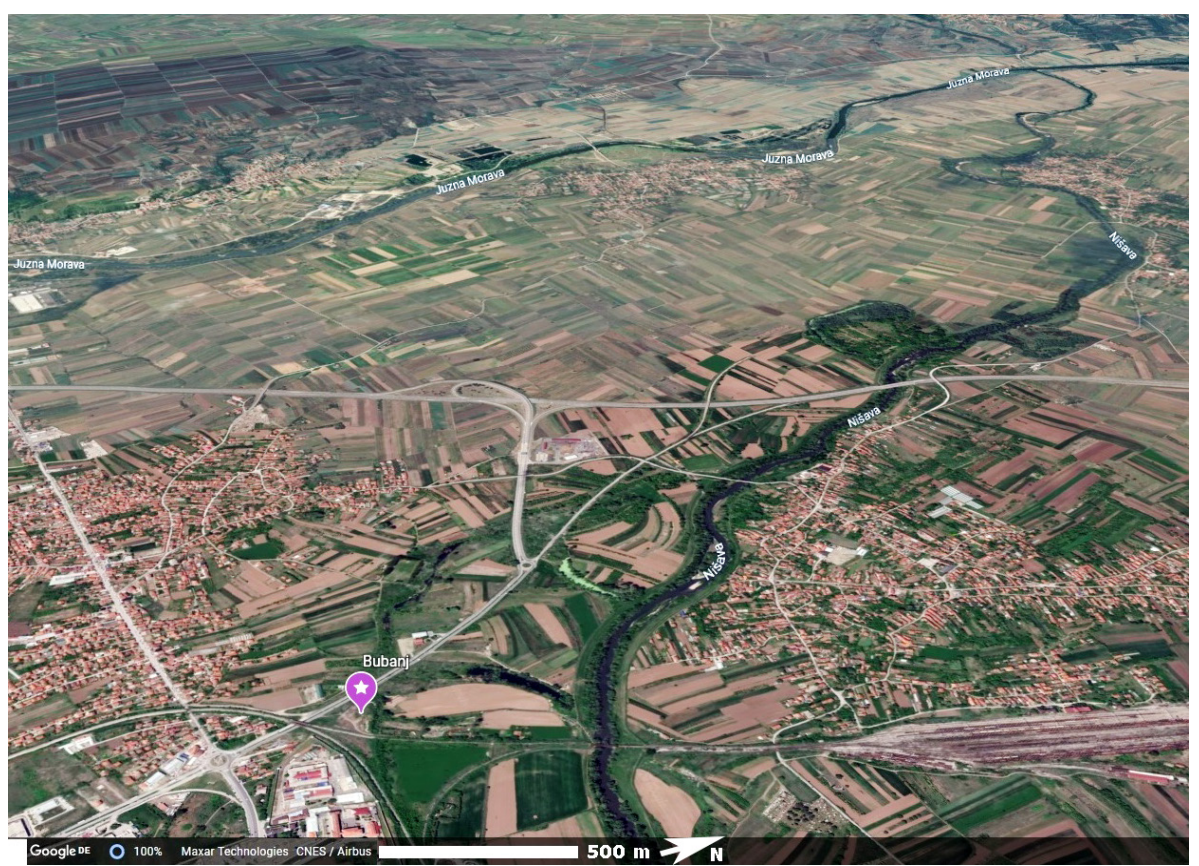

Fig. 5. Google Earth image of the location of Bubanj in the Južna Morava-Nišava interfluve, southern Serbia (C) Google)

Сл. 5. Позиција локалитета Бубањ у међуречју Јужне Мораве и Нишаве, Google Earth сателитски снимак

(15 $\mathrm{m}$ high) on which the site is situated extends further to the east, up the Nišava river. It overlooks the extensive alluvial plain of the Južna Morava to the south and the west, whereas to the north it used to be immediately bordered by the Nišava; this changed in the 20th century when the river bed was relocated further northwards. The area around the site is covered by alluvial soils shaped and re-worked by the changing, meandering Nišava course. Prior to the recent river 
channelling, the dynamic river course probably created pockets or larger areas of wetland environment, in addition to the zones seasonally flooded by the Južna Morava (Милановић и Трајковић-Филиповић 2015). It is conceivable that the patterns and flow regimes of the two rivers governed the soil and vegetation cover in much of the site's surrounding. The macro-plant assemblage from Eneolithic Bubanj contains remains of both dry land and wet-loving flora and it is possible that there was a mosaic of vegetation forms around the site, with (seasonally) dry areas or higher ground used for crop cultivation. Among the cultivated crops most prominent were einkorn (Triticum monococcum), emmer (T. dicoccum), barley (Hordeum vulgare) and lentil (Lens culinaris) (Filipović 2020).

The faunal record from Eneolithic Bubanj shows a similar quantitative representation of sheep/goat and cattle, with a slightly higher proportion of sheep/ goat remains. The presence of pig was relatively low in the Early Eneolithic but increased through time and approached that of sheep/goat and cattle in the Late Eneolithic (Bulatović 2020). The prominence of sheep/goat in the assemblage may reflect their overall dominance and high importance to the residents, perhaps because of their close integration with arable farming, primarily of sheep (cf. Halstead 2000, 2006). Pigs may also have had a role in the crop cultivation routine - to clear land and break up clayey soils. Perhaps this led to their apparently greater role in the Late Eneolithic settlement at Bubanj (Bulatović 2020), especially if new areas for cropping needed to be cleared. Cattle could have browsed on pannage in riparian woodland, along with pigs and goats, or grazed on alluvial grassland and crop stubble; if manuring of arable fields was practiced, cattle would have served as a key source of manure (Halstead 1987, 2000: 121). Seasonal transhumant herding in the uplands about a dozen kilometres to the north or south could also have been practiced, perhaps of small ruminants (cf. Arnold and Greenfield 2006: 30, 121; Halstead 2000: 121), as a way of keeping the animals away from arable areas during key periods of crop growth and agricultural field work. Greenfield (1999: 31; Arnold and Greenfield 2006: 1, 122) suggested that, following the Neolithic, transhumant pastoralism could have enabled colonisation of agriculturally marginal lands of southeast Europe, principally highlands. However, there have been no conclusive evidence of this form of mobility in the Eneolithic due to the insufficient data and small size of the available faunal assemblages (Arnold and Greenfield 2009: 122). We concede that this is also the problem with the Bubanj dataset as well as other Eneolithic collections of animal remains from Serbia. Even so, mobile herding remains a possibility and can be viewed as an adjustment of former management strategies to maximise the yield of secondary animal products (cf. Sherratt 1993). 


\section{Animals at Late Neolithic and Eneolithic sites in Serbia}

The zooarchaeological assemblages have been analysed for several sites located south of the Danube, in central (eastern and western) and southern Serbia (Fig. 3). They show that the Eneolithic in this region was characterised by rearing of cattle (Bos taurus), sheep (Ovis aries), goat (Capra hircus) and pig (Sus domesticus). In the record of wild animals, the best represented are red deer (Cervus elaphus), roe deer (Capreolus capreolus) and wild boar (Sus scrofa). All of the listed species occur - moreover, dominate - in the animal bone collections from Late Neolithic sites in Serbia. Therefore, an initial impression is that animal-based economy did not change much during the 5th millennium $\mathrm{BC}$, i.e. the Neolithic-Eneolithic transition. However, a simple comparison of livestock spectra from the period before and after the mid-5th millennium BC is devalued by the low data availability for the Eneolithic. There is a relatively large number of publications presenting the results from Late Neolithic sites and discussing the animal economy of Vinča culture communities (e.g. Bökönyi 1988; Legge 1990; Russell 1993; Dimitrijević 2008; Orton 2008, 2012; Bulatović 2018). On the other hand, there is information for only one location where the occupation seems to have started immediately following the end of the Vinča culture in Serbia. This is the Early Eneolithic site of Bodnjik in western Serbia (Borić 2009; Bulatović, Vander Linden 2017), but the faunal assemblage from it is exceedingly small, with NISP ${ }^{1}$ as low as 37 (Bulatović 2018: 344, D1.4). Similar problem exists with the datasets from later phases of the Eneolithic, such as from the sites of Nad Klepečkom and Rit in eastern Serbia (Vuković and Marković 2019), Novačka Ćuprija in central Serbia (Greenfield 1986) and two sites in northern Serbia, in the Srem region, Zlatara-Ruma and Pirovac-Ruma (Блажић 1995). Furthermore, the taphonomy of the remains has in some cases not been unresolved (for more details see Greenfield 1986; Стојановић и Булатовић 2013).

Only a handful of Eneolithic sites yielded faunal assemblages that are, in terms of their size, suitable for more detailed consideration and crosscomparison conducted in this study. ${ }^{2}$ These are Kudoš-Šašinci (Блажић 1995), Vinča-Belo Brdo (Лазић 1992), Petnica (Greenfield 1986), Mokranjske Stene

\footnotetext{
${ }^{1} \mathrm{NISP}=$ Number of Identified Specimens

${ }^{2}$ With a minimum NISP $\geq 150$ of identified macromammal specimens. This value is comparable to those used in some recent zooarchaeological studies of the central-western Balkans. Namely, Gaastra et al. 2019 apply a cut-off value of 100, and Orton et al. 2016 use a minimum NISP of 200. The study of the faunal assemblage from Bubanj (presented in Bulatović 2010 and Bulatović 2020) demonstrated that the percentages of individual species remained unchanged when calculated based on low NISP values (those resulting from preliminary analyses) and those based on higher NISP values (obtained after the analyses were completed). This gives us confidence that the patterns we see in proportions of the remains can reflect changes in animal husbandry over time.
} 


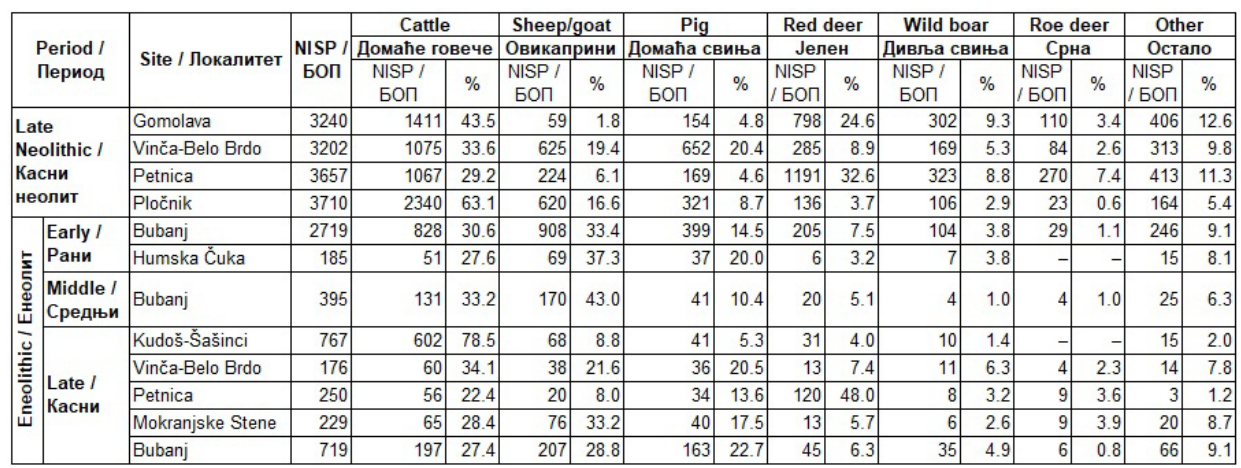

Table 2. NISP values and frequencies (relative quantities in \%) of domestic and wild animals at Neolithic and Eneolithic site in Serbia; only Eneolithic sites with NISP $\geq 150$ are considered here

Табела 2. БОП вредности (број идентификованих примерака) и процентуална заступљеност домаћих и дивљих животињских врста на неолитским и енеолитским локалитетима у Србији; у раду су размотрени искључиво енеолитски локалитети са 150 и више идентификованих примерака

(Булатовић и Милошевић 2015), Humska Čuka (Bulatović 2018: 345, D1.5) and Bubanj (Bulatović 2018, 2020). In order to compare the Eneolithic datasets with those from the Late Neolithic, we use the results from several Vinča culture sites with representative assemblages: Gomolava (Orton 2008), Vinča-Belo Brdo (Bulatović 2018), Petnica (Orton 2008) and Pločnik (Bulatović 2018). We focus on the most commonly occurring domestic and wild species mentioned above. Because of the significant morphological overlap between osteological elements of sheep and goat, many of their generally poorly preserved remains from these sites could not be attributed to one or the other genus with sufficient certainty. Therefore, they are here included as a single taxonomic category (sheep/goat). Table 2 shows frequencies (i.e. relative proportions) of the major species within the total number of identified animal remains (\% NISP) from the selected Neolithic and Eneolithic sites. The so far produced results for the Early, Middle and Late Eneolithic occupation phases at Bubanj are given separately. Figure 6 illustrates the frequencies of the main animal species through time, based on the data given in Table 2.

In comparison to the Vinča culture sites, where cattle appears to have been the most important animal resource (cf. Russell 1993; Orton 2008; see also Spasic 2012), the Eneolithic sites reveal a temporal trend towards potentially greater-than-before role of sheep/goat and pig in this period. The beginning of this trend is visible immediately following the end of the Vinča culture, as demonstrated by the composition of Early Eneolithic assemblages from Bubanj and 


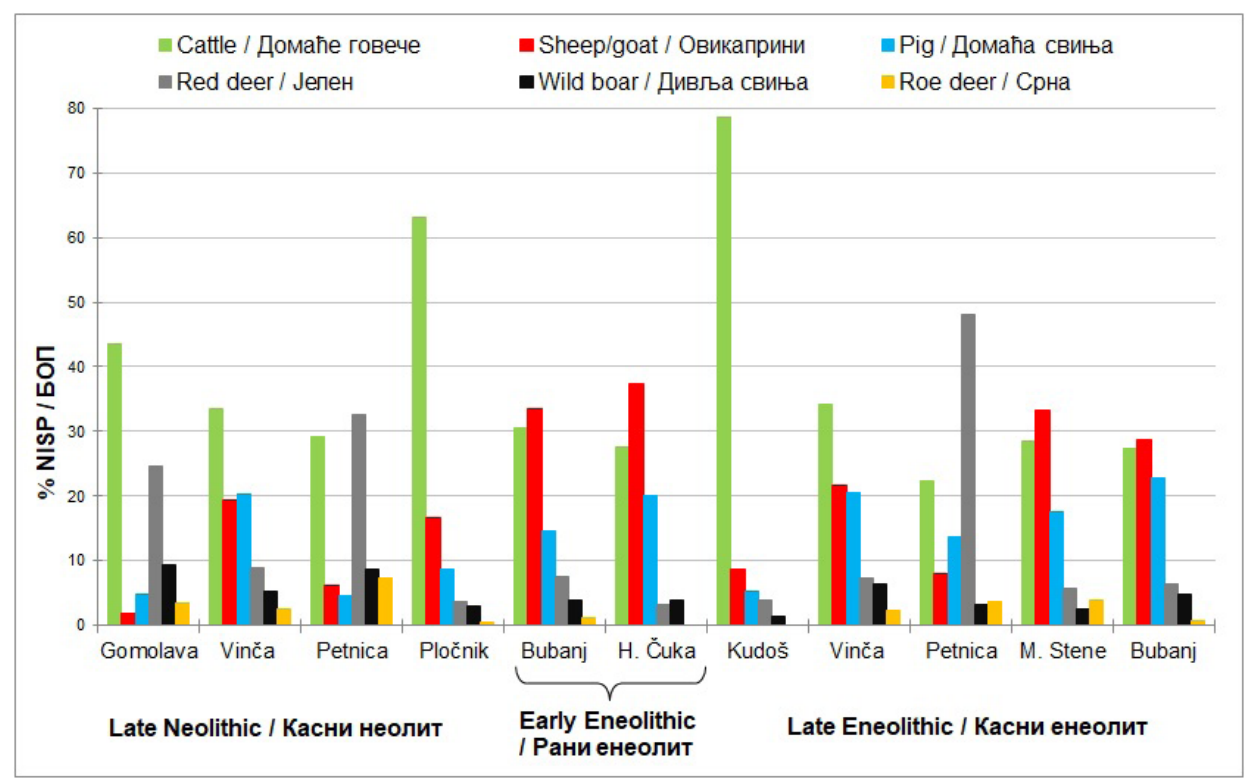

Fig. 6. Frequencies (relative quantities in \%) of domestic and wild animals at Neolithic and Eneolithic sites in Serbia; only Eneolithic sites with NISP $\geq 150$ are considered in this study

Сл. 6. Процентуална заступљеност домаћих и дивљих врста животиња на неолитским и енеолитским локалитетима у Србији; у раду су размотрени искључиво енеолитски локалитети са 150 или више идентификованих примерака (број идентификованих примерака - БОП $\geq 150$ )

Humska Čuka. The prominence of sheep/goat characterises the later phases of the Eneolithic too. However, rather than a region-wide tendency, this development seems to have been linked with different cultural traditions represented at the study sites. For instance, Late Eneolithic layers at Mokranjske Stene and Bubanj have been attributed to the Coţofeni-Kostolac culture circle; they both contained high proportions of sheep/goat remains. Unlike these two sites in eastern and southern Serbia, the assemblages from both Neolithic and Late Eneolithic layers at Petnica (western Serbia) are characterised by low percentages of sheep/goat versus high percentages of cattle and especially red deer. Late Neolithic/Vinča culture layer at Gomolava also produced high proportions of cattle and red deer, and very little sheep/goat.

At Late Eneolithic Kudoš-Šašinci, the largest number of faunal remains derived from cattle. This site has been associated with the Tiszapolgár culture of the Carpathian Basin, for which it was initially suggested that the animal-based economy was focused on herding and consumption of cattle (Bökönyi 1986). 
However, more recent analysis of several sites of this culture in Hungary has demonstrated the predominance of sheep and goat among domestic animals. It has also been suggested that wild animals and hunting had less important role in the Eneolithic compared to the Neolithic (Weinstein 2007). It is possible that there were differences in food production strategies, such as in the choice and degree of use of domesticates, between communities that shared aspects of material culture. Perhaps this was typical of extensive and ecologically diverse biogeographical regions, such as the Carpathian Basin, even at times when they were characterised by generally uniform cultural traditions. This was the case with the Vinča groups as well. For example, the amount of cattle remains found at Pločnik is unusually high when observed alongside other contemporary sites considered here (Fig. 6). On the other hand, it corresponds to the situation encountered in the Vinča culture layer at the site of Divostin, where nearly $50 \%$ of the remains of domesticated fauna came from cattle (Bökönyi 1988). There may have been both cultural and ecological reasons behind the apparent preference for cattle by these communities, as discussed elsewhere (Russell 1993; Greenfield 1991, 2014; Orton 2008, 2012; Блажић и Радмановић 2011; Bulatović 2018; Bulatović and Orton in press; Orton et al. in press; Stojanović and Orton in press).

The data presented here enable a diachronic perspective at the site level. The Late Neolithic and Late Eneolithic records from Vinča-Belo Brdo are almost identical in their composition (Fig. 6). At Petnica, when compared to the Late Neolithic, the assemblage from the Late Eneolithic layer consists of lower proportions of some wild taxa (wild boar and roe deer) and higher proportions of pig and red deer. There seem to have existed both continuity and discontinuity through time in the choice of animals to herd and hunt at these locations. The results from Early, Middle and Late Eneolithic Bubanj show almost unchanged relative presence of cattle and sheep/goat over the duration of the settlement, whereas the importance of pig increased in the course of the Eneolithic. In general, the percentages of domestic pig are consistently higher at Eneolithic relative to Late Neolithic sites in Serbia, with the exception of Kudoš-Šašinci. Since pigs do not generate secondary products, this tendency could reflect growing importance of pig in meat and fat provision, perhaps due to other livestock becoming more valued for their secondary products. As noted above, pigs may also have been used to clear new land for cropping and turn the soil.

As regards the wild taxa, at the majority of sites discussed here their presence is much lower than that of domestic animals, and remains such throughout the period. Red deer is found everywhere, and in higher percentages than wild boar and roe deer, which reflects its continual significance as a source of food 
and raw material. All but one of the sites included in this study contained remains of all three major hunted animals, suggesting the availability of, and interest in, these resources in both periods and in different parts of the study region. This will pertain to any future investigations into changes in the landscape, including the natural habitats of these species, resulting from human activity and/or palaeoenvironmental change in this phase of prehistory of the central Balkans.

The so far analysed zooarchaeological assemblages from Late Neolithic and Eneolithic sites in Serbia offer a good picture of the range of domestic and wild animals kept or hunted for food and other purposes during the 5th and 4th millennia BC in the central Balkans. They show that the same faunal spectrum was available and used throughout this period, in various parts of the region, reflecting continuity in the choice of animal resources across the Late Neolithic-Eneolithic transition. They also reveal some intra-regional and inter-site synchronic and diachronic differences in the degree of use of different taxa. Two overall trends can broadly be discerned at the regional level based on the presence/absence and frequencies of the remains of major species in the Late Neolithic and Eneolithic records: (a) greater presence of sheep/goat and pig in the Eneolithic, lower of cattle; (b) lower percentage of wild fauna, most prominently of red deer and wild boar in the Eneolithic. In the assemblage from Bubanj, a further diachronic change is evident - increase in the proportion of pig from the Early to the Late Eneolithic (Bulatović 2020).

\section{Plants at Late Neolithic and Eneolithic sites in Serbia}

As with the zooarchaeological data, there is much more archaeobotanical information for the Late Neolithic than for the Eneolithic period in the central Balkans. In contrast to over a dozen studied Vinča culture sites, only a few sites from the later part of the 5 th and the 4th millennium BC have been analysed (Fig. 3). The work at Bubanj was, therefore, of high significance because it introduced regular collection of soil samples for the extraction of plant remains, recovery by way of flotation and detailed analysis of the material. A similar procedure was applied in the investigations of Humska Čuka, another Eneolithic tell-site in southern Serbia, located very close to Bubanj.

Despite the overall low number of archaeobotanical remains retrieved from Bubanj, the assemblage is diverse and includes traces of various plant-related activities - crop cultivation and processing, discard of by-products, collection of wild fruit, gathering of wood fuel (Filipović 2020). Previously, the only available data on plant use in the Eneolithic were those for the Coţofeni-Kostolac culture layer at Gomolava in northwestern Serbia (van Zeist 2002). Recently, in the 


\begin{tabular}{|c|c|c|c|c|c|c|c|c|c|c|c|c|c|c|c|c|c|c|}
\hline Period / Период & & & $\begin{array}{l}\text { La } \\
\text { acH }\end{array}$ & $\begin{array}{l}\mathrm{e} \mathrm{Ne} \\
\mathrm{Hec}\end{array}$ & $\begin{array}{l}\text { olit } \\
\text { лит }\end{array}$ & $\begin{array}{l}\text { hic } \\
\text { (B) }\end{array}$ & $\begin{array}{l}\text { Vin } \\
\text { НЧ }\end{array}$ & ča & $\begin{array}{l}\text { ultt, } \\
\mathbf{a}_{\mathbf{~}}\end{array}$ & лтуу & & & & & & $\begin{array}{l}\text { olith } \\
\text { еол }\end{array}$ & & \\
\hline Crop type / Гајена врста & 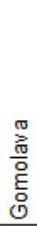 & 흥 & 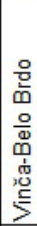 & 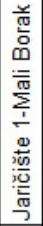 & 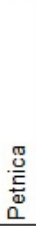 & 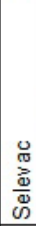 & 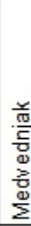 & 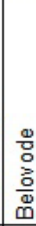 & 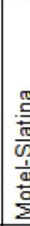 & 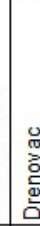 & 吾 & & 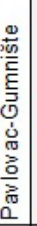 & 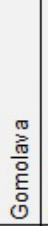 & 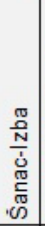 & 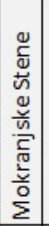 & & 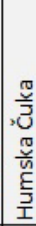 \\
\hline einkorn / једнозрна пшеница & $\mathrm{X}$ & $\mathrm{x}$ & $\mathrm{x}$ & $\mathrm{x}$ & $\mathrm{X}$ & $x$ & $\mathrm{x}$ & $\mathrm{x}$ & $x$ & $\mathrm{x}$ & $x$ & & $\mathrm{X}$ & $\mathrm{x}$ & $x$ & $\mathrm{x}$ & $\mathrm{x}$ & $\bar{x}$ \\
\hline emmer / двозрна пшеница & $\mathrm{X}$ & $\mathrm{x}$ & $\bar{x}$ & $\mathrm{x}$ & $\mathrm{X}$ & $\mathrm{x}$ & $\mathrm{x}$ & $\mathrm{x}$ & $x$ & $\mathrm{x}$ & $\bar{x}$ & & $\mathrm{x}$ & $\mathrm{x}$ & $\mathrm{x}$ & $\mathrm{x}$ & $\mathrm{x}$ & $x$ \\
\hline 'new type' glume wheat / пшеница "нови тип" & & & $\mathrm{x}$ & $x$ & & & & $\mathrm{x}$ & & $\mathrm{x}$ & $x$ & & $\mathrm{X}$ & & & & & \\
\hline free-threshing wheat / хлебна/дурум пшеница & $\mathrm{X}$ & & $\mathrm{x}$ & & & & $\mathrm{X}$ & $\mathrm{x}$ & $\mathrm{x}$ & & $x$ & & & $\mathrm{X}$ & & $\mathrm{x}$ & & $\mathrm{x}$ \\
\hline barley / јечам & $\mathrm{X}$ & $\mathrm{x}$ & $\mathrm{x}$ & $\mathrm{x}$ & $\mathrm{x}$ & $\mathrm{x}$ & & $\mathrm{x}$ & & $x$ & $x$ & & $\mathrm{X}$ & $\mathrm{X}$ & & & $\mathrm{x}$ & $\bar{x}$ \\
\hline lentil / сочиво & $\mathrm{x}$ & $\mathrm{x}$ & $\mathrm{x}$ & $x$ & & $\mathrm{x}$ & & $\bar{x}$ & $\mathrm{x}$ & $\bar{x}$ & $\bar{x}$ & & $\mathrm{x}$ & $x$ & & $\mathrm{x}$ & $\mathrm{x}$ & $\mathrm{x}$ \\
\hline pea / грашак & $x$ & & $\mathrm{x}$ & & & $\mathrm{x}$ & & $\bar{x}$ & & $x$ & $x$ & & $x$ & & & $\mathrm{x}$ & $x$ & \\
\hline bitter vetch / грахорица & & & $\mathrm{X}$ & $\mathrm{x}$ & & & & $\bar{x}$ & & $\mathrm{x}$ & $x$ & & $\mathrm{x}$ & $\mathrm{X}$ & & & $\mathrm{x}$ & $\mathrm{x}$ \\
\hline grass pea / граop & & & & & & & & $\mathrm{x}$ & & & $x$ & & $\mathrm{x}$ & & & & & \\
\hline flax/linseed / лан & $\mathrm{X}$ & $\mathrm{X}$ & $\mathrm{X}$ & $\mathrm{x}$ & & & & $\bar{x}$ & & $x$ & $\gamma$ & & $\bar{x}$ & $x$ & & & $x$ & \\
\hline
\end{tabular}

Table 3. Presence/absence of the crop types recorded at Late Neolithic and Eneolithic sites in Serbia

Табела 3. Пољопривредне културе забележене на каснонеолитским и енеолитским локалитетима у Србији

region of Mačva in western Serbia, one of the "obrovac-type" sites (Šanac-Izba near Lipolist) dating from the Early Eneolithic was sampled for plant remains (Трипковић и др. 2017). Unfortunately, it yielded little and badly preserved plant material, including few grains of einkorn and emmer. The Early Eneolithic layer at Mokranjske Stene produced a small botanical collection which, nonetheless, enabled identification of at least some of the plants consumed at this site (Филиповић 2015). Analysis of the botanical remains retrieved from Humska Čuka is under way (Булатовић и Филиповић in press) and the initial results are referred to here.

Table 3 lists the crops likely cultivated at the so far examined Neolithic and Eneolithic sites in Serbia. Evidently, the spectrum of plants grown in the 5th and 4th millennia $\mathrm{BC}$ in the region is wide and generally consistent throughout this period. There are, however, a few species found at Neolithic sites that are apparently 'absent' at Eneolithic sites. For instance, at the site of Pločnik about 30 $\mathrm{km}$ west of Bubanj, two types of wheat were registered that were not documented at Bubanj: 'new type' glume wheat (Triticum timopheevi group) and free-threshing wheat (T. durum/aestivum). Further, bitter vetch (Vicia ervilia) is present in greater quantities at Late Neolithic sites of Vinča-Belo Brdo and Belovode than at Bubanj (Filipović 2020, in press a, b). Differences in the representation of some of the taxa could be due to the limited size of the Eneolithic record relative 


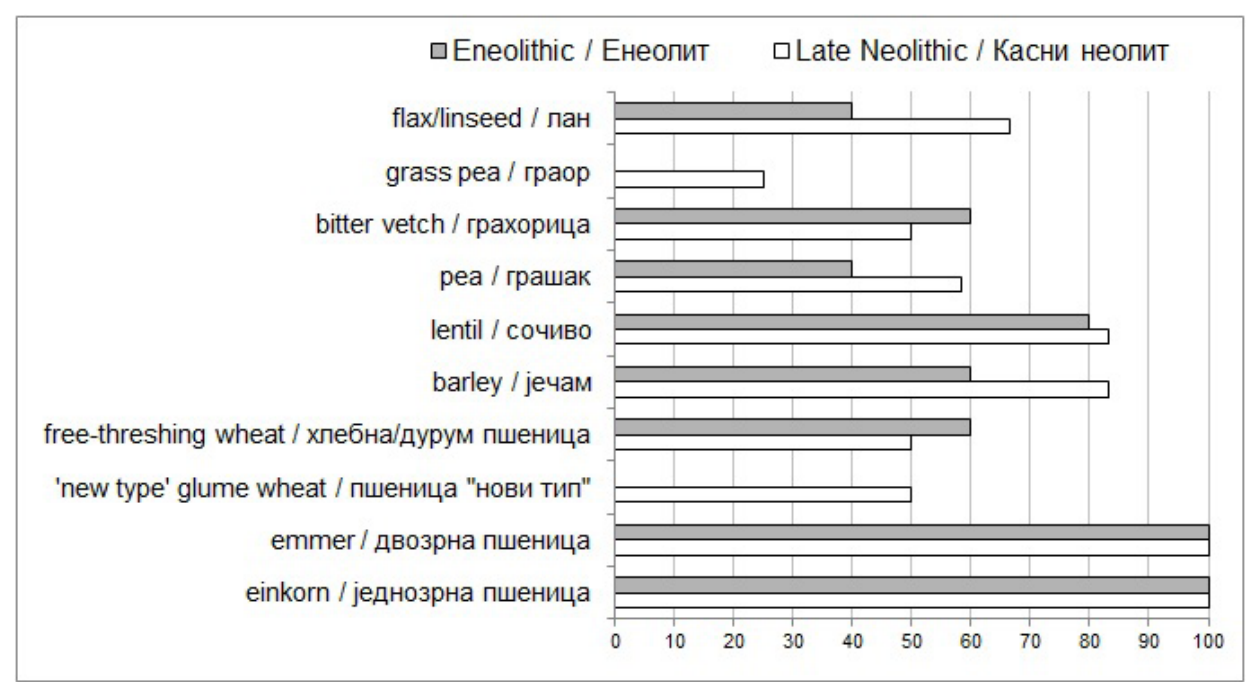

Fig. 7. Percentage of Late Neolithic $(n=12)$ and Eneolithic $(n=5)$ sites in Serbia at which the different documented crop types occur

Сл. 7. Проценат локалитета касног неолита $(n=12)$ и раног енеолита $(n=5)$ у Србији на којима се јављају различите пољопривредне културе

to that from the preceding period. It is, thus, difficult to speak about possible 'narrowing' of the crop spectrum or other changes in it after the Neolithic. Nevertheless, a look at the presence/absence of various crop taxa at the regional level may hint at potential trends in the choice of cultivars.

Figure 7 shows the number of Late Neolithic sites at which the crops characterising this period occur; twelve sites are considered using the information summarised in some recent publications (e.g. Filipović and Obradović 2013; Filipović 2014). According to this overview, the most common crop types are einkorn and emmer, followed by barley, lentil and flax (Linum usitatissimum); free-threshing wheat, pea (Pisum sativum) and bitter vetch were found at about half of these sites; grass pea (Lathyrus sativus/cicera) was discovered in only two locations. A similar regional perspective is not possible for the Eneolithic because the data exist only for five sites (Table 3). It is, however, worth comparing the composition of the assemblages derived from two presumably contemporary layers at Bubanj and Gomolava - those attributed to the Late Eneolithic/Cotofeni-Kostolac culture - although the dataset from Gomolava is much larger than the corresponding one from Bubanj (Table 4). At least based on the range of crops represented, the two assemblages look similar (see Table 5).

The record from Gomolava is particularly interesting because of the abundance of barley in it, which may suggest that barley was here the most im- 


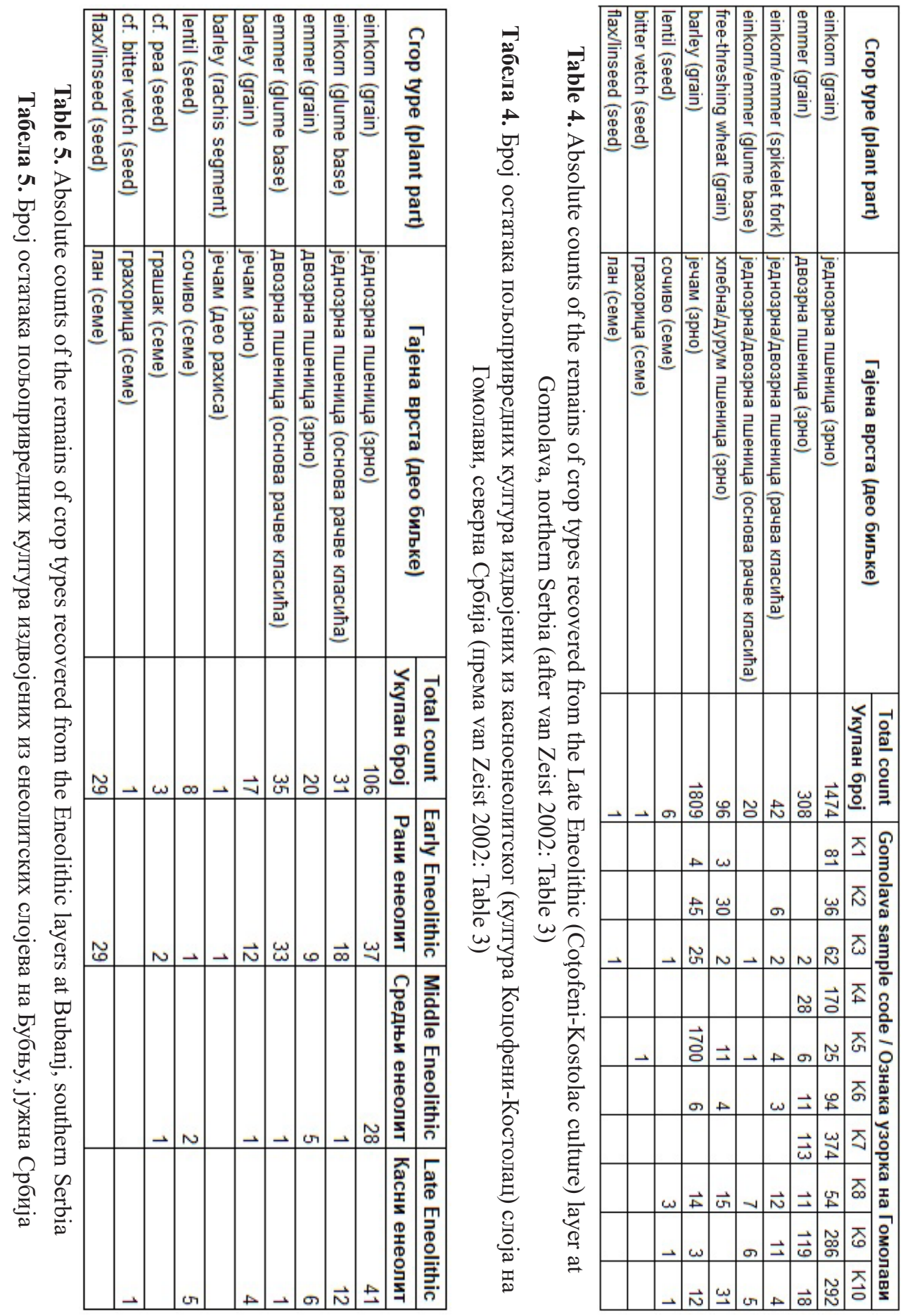


portant crop type. Most of the c. 1800 barley grains from Eneolithic Gomolava came from a single context described as the "remains of a basket" (van Zeist 2002: Table 1). The rest of the Eneolithic contexts contained much fewer or no barley grains (Table 4). This makes the site distinct from other Late Neolithic and Eneolithic sites in the central Balkans, including the Late Neolithic layer at Gomolava itself, where barley was relatively frequent but found in very small quantities (van Zeist 2002: Table 2). At Gomolava, einkorn grain was present in at least $95 \%$ of the analysed Late Neolithic and in all of the analysed Eneolithic contexts; in case of the latter, it was nearly as abundant as barley. It seems that einkorn was more regularly used and/or deposited than barley, which is comparable to the situation observed at other Neolithic and Eneolithic sites in Serbia (Filipović 2014). It is noteworthy that barley is prominent at Late Neolithic and Eneolithic sites in Hungary, along with einkorn and emmer (Gyulai 2010: 88, Table 3 ) and perhaps this also exemplifies inter-regional differences in the choice of cultivars. Although found in Neolithic and Eneolithic layers at Gomolava (and some other sites in Serbia), broomcorn millet grains are intrusive since they are much younger than the age of these layers, as has now been confirmed by radiocarbon dates on the grains (Filipović et al. 2020).

Acknowledging the limited archaeobotanical evidence, the plant remains from Bubanj still offer an opportunity to explore potential changes at the site level in the crop spectrum through the Eneolithic. Figure 8 depicts the percentage ubiquity ${ }^{3}$ of crops across securely defined contexts (features) from different settlement phases of this site. ${ }^{4}$ The number of crop remains per phase is given in Table 5. These results indicate that most of the detected crops were in use during the entire Eneolithic occupation, with glume wheats (einkorn and emmer) as the likely staples. This compares well to the picture for the Late Neolithic in the central Balkans. Although the quantities at Bubanj may suggest that emmer drops in importance through time, these numbers are rather low and quite a few glume wheat grains could not be identified with precision. The similar is true of barley, lentil and pea, found only in traces. The absence of flax/linseed, however, is probable, at least in the Late Eneolithic when it is also virtually absent from a much richer botanical dataset from Gomolava (only one seed was found; van Zeist 2002: Table 3).

Drawing on the available data from Serbia, our general impression is that plant food production in the 5th and 4th millennium BC in the central Balkans relied on several cereal and legume crops, of which einkorn and emmer likely

\footnotetext{
${ }^{3}$ The percentage of contexts in which these crops occur.

${ }^{4}$ See Filipović 2020 for detailed sample-by-sample archaeobotanical data for Bubanj.
} 


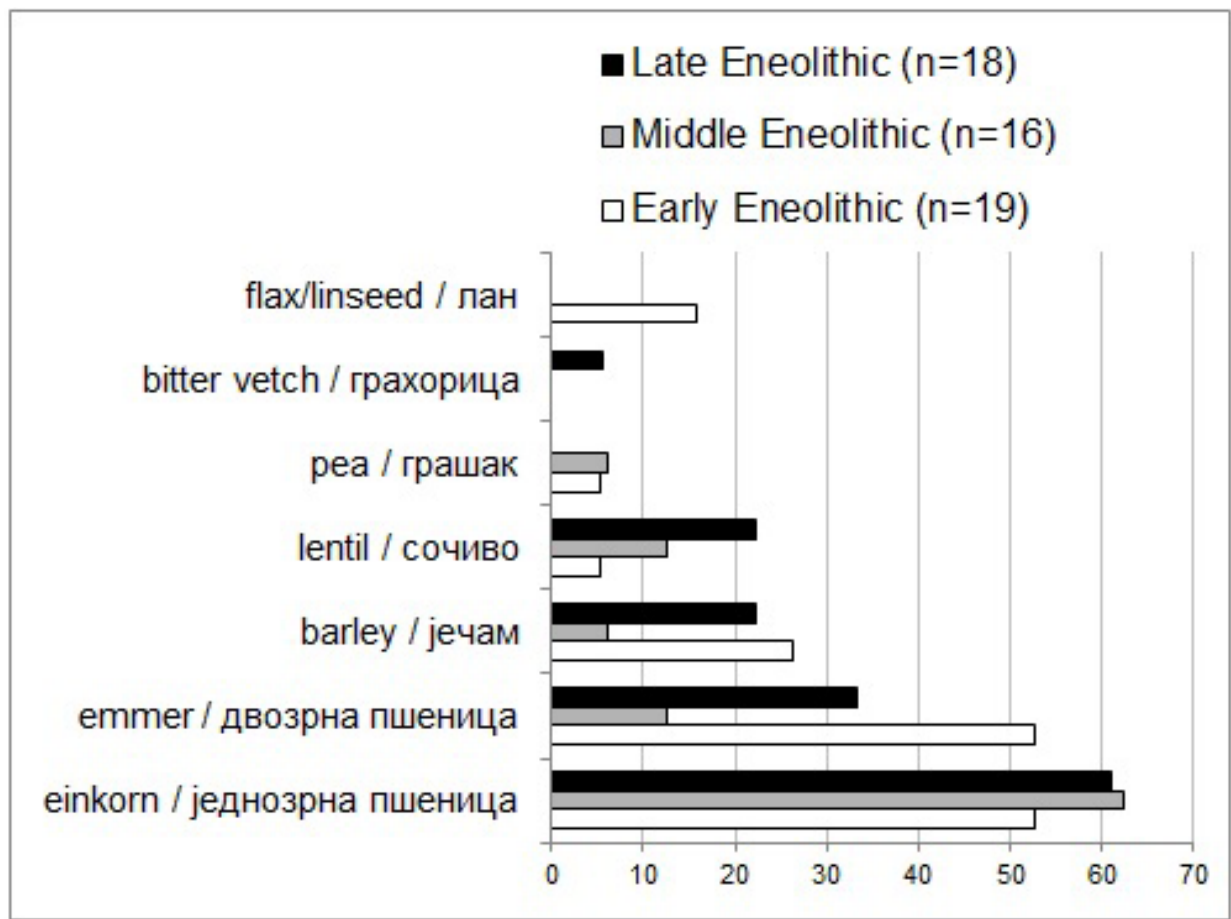

Fig. 8. Percentage of contexts/features at Bubanj, from different phases of the Eneolithic occupation, containing the documented crop types

Сл. 8. Проценат целина (контекста) из различитих фаза енеолитског насеља на Бубњу у којима се јављају наведене пољопривредне културе

were at the core of plant economy. No major changes in the crop spectrum are observed for the period of Late Neolithic-Early Eneolithic transition, suggesting an overall continuity in the choice of cultivars. It is, however, possible that the role (e.g. food vs. fodder) or importance of some crops changed during this time, and especially towards the Late Eneolithic, as to some extent indicated by the evidence from Late Eneolithic Gomolava and Bubanj. It was pointed out before that the degree of use of certain crops varied between the settlements in the region characterised by the Vinča culture phenomenon (Filipović 2014). The spectrum of cultivated resources seems to have differed between these settlements too (Обрадовић 2020). Such variability perhaps reflects diverse agricultural practices and methods, and/or different knowledge of crop properties and cultivation techniques. Local topography and environment could have played a role in this too (cf. Gaastra et al. 2019), as well as possible specialisation of the communities for a certain economic activity, such as ore or salt extraction or animal husbandry (Kapuran and Milošević 2013: 25-26; Kapuran et al. 2018). 
The continuity in the repertoire of cultivated crops from the Neolithic into the Eneolithic may indicate that cultivation strategies remained unchanged during this long period. The results of archaeobotanical and stable isotopic analysis of Neolithic sites in different parts of southeast Europe support the model of generally small-scale, intensive agricultural regime, with high labour and time investments into small cultivation plots that were thoroughly tilled, regularly weeded and manured in order to secure (high) yields (Bogaard et al. 2013; Bogaard and Halstead 2015; Allen 2017). Perhaps this model can be applied to Eneolithic agriculture in the central Balkans, but the data we have are too limited for any conclusions on this. Besides more archaeobotanical data that may become available in the future, other forms of evidence could be considered as relevant for the identification of possible changes in the agricultural choices and techniques. At Bubanj, for instance, a diachronic change was observed in the shape of flint pieces that formed parts of composite tools potentially used for cutting plant materials, as concluded based on the presence of gloss along their edges (Šarić 2020). The pieces could have been inserted in tools such as sickles and threshing sledges (Šarić 2020: 393, 409). Their form changed from the Early to Late Eneolithic, and the later ones may have rendered the composite tools more efficient (Šarić 2020: 410). Perhaps this had implications for the harvesting method, though the tools may not have been meant (exclusively) for harvesting crops.

Similarly to the evidence from Serbia, an overall continuity in agricultural production was observed across the Late Neolithic-Early Eneolithic transition and through the Late Eneolithic in continental Croatia. This is visible in the range and quantity of crops, of which the main were emmer, einkorn and probably also barley (Reed 2017). It appears that barley was here more frequent in the Eneolithic compared to the Late Neolithic, and the same may apply to flax/linseed, although the number of remains is relatively small, especially for the Early/Middle Eneolithic. It was concluded that there was no dramatic change in agriculture after the Late Neolithic and during the Eneolithic in northern Croatia and that the crop and animal husbandry were equally important (Reed 2017). This is opposite to what was suggested for the Eneolithic in Hungary, where post-Neolithic decline in crop production was postulated based on the low quantities of crop remains found. Unfavourable climate and a shift to predominantly animal-based economy were seen as possible reasons for this change (Gyulai 2010: 87-88). The Late Eneolithic sites here contained more cereal remains, particularly barley and einkorn, perhaps reflecting an increase in agricultural activity due to improved climatic conditions towards the end of the period. However, the number of plant remains recovered from archaeological sites depends heavily on the formation 
processes, preservation and sampling methodology, as was demonstrated for Croatia (Reed 2017). Thus, the low numbers alone should not be taken as indicating low importance of crop cultivation in general.

\section{Conclusions and questions for the future}

Notwithstanding the scarcity of the sites analysed, limited size of the datasets, uneven regional coverage and, in some cases, insecure or inadequate sampling and analytical methodology, this overview offers a useful insight into animal- and plant-based food economy of the central Balkans in the 5th and 4th millennia $\mathrm{BC}$ - during the Late Neolithic and Eneolithic periods. It enables placing of the evidence from Eneolithic Bubanj into a wider chronological and geographical context. Further, by looking at the composition of the faunal and floral assemblages and the proportional representation of taxa, we have identified certain similarities and differences between the sites and periods.

There is a general continuity in the taxonomic spectra of crops and animals (herded and major hunted species) from the Neolithic into and during the Eneolithic. At Eneolithic sites, the remains of sheep/goat and pig appear more abundant, whereas cattle is less represented. This is quite clear at Bubanj, where a diachronic perspective at the site level is possible. The trend may be indicative of an increase in importance of caprines and pig relative to cattle, which is different to the situation observed at most of the Late Neolithic sites, where cattle prevails. The data also show that there are exceptions to this general observation. For instance, at the site of Vinča-Belo Brdo, proportions of domesticates are virtually the same in the Late Neolithic and Late Eneolithic assemblages. At Late Eneolithic Kudoš-Šašinci, the vast majority of the remains belong to cattle. As an interim conclusion, in the Eneolithic, the importance of cattle and wild animals (especially red deer) seems to have been lower than before, whereas sheep/goat and pig may have had a more prominent place in the economy. There are exceptions to this potential pattern.

Both Neolithic and Eneolithic plant assemblages from the central Balkans are mainly composed of einkorn and emmer, followed by barley. Pulses, of which lentil, pea and bitter vetch have been recorded, are much less visible. Flax/ linseed has not been registered at Eneolithic sites. The regional archaeobotanical picture suggests continued cultivation of very much the same set of crops through the 5th and the 4th millennium BC, but with probable differences in the importance or role of some crops between the sites and through time. This variability maybe reflects differences in the agricultural methods or cultural preferences, and/or may have been a result of environmental constraints and affordances in the biogeographically diverse study region. 
The available evidence of economic practices does not suggest any major changes in food production during or immediately after the time of cultural transformations at the end of the Late Neolithic/start of the Early Eneolithic in the central Balkans. In other words, the diachronic changes seen in certain aspects of life and material culture do not find parallels in plant and animal husbandry. It is highly possible, however, that the data collected so far are insufficient to detect changes, especially if they were minor, during the transitional period. As one moves later into the Eneolithic, visible differences emerge in the range and quantity of plant and animal resources in comparison to the Late Neolithic, at the regional and site levels. Perhaps they indicate new economic practices, which could have been developed in response to the proposed disintegration or reorganisation of the Late Neolithic/Early Eneolithic society.

Key questions remain as to which particular strategies are reflected in the here-described trends and variations in the composition of plant and animal assemblages. For instance, the importance of animals generating secondary products and those used as main sources of meat may have shifted over time. Livestock management would have been shaped to account for or promote these changes; for example, new practices, such as (more) mobile herding, could have been introduced. Plant production may have placed greater emphasis on growing of crops for fodder; this, in turn, would have had a bearing on aspects such as the scale and intensity of cultivation, agricultural routine, organisation of labour, specialisation of production. A further set of questions can be posed about how the changes or adjustments in food economy articulated with social, technological, and ideological transformations associated with this period. The environmental context in which these developments took place is also of interest and may have influenced decisions and choices of the food producers. Future research should be designed to address these questions, which are vital to understanding the dynamics of post-Neolithic society and economy in the central Balkans.

Acknowledgements: DF acknowledges the support of the German Research Foundation (Project Ref. 2901391021 - SFB 1266) in the preparation of this paper.

\section{REFERENCES}

Allen, S. E. 2017. Cultivating identities: Landscape production among early farmers in the Southern Balkans, in Balkan Dialogues: Negotiating Identity between Prehistory and the Present, eds. M. Gori and M. Ivanova, 213-239. Routledge: Oxford/New York.

Arnold, E. and Greenfield, H. 2006. The Origins of Transhumant Pastoralism in Temperate South Eastern Europe: A Zooarchaeological Perspective from the Central Balkans. Oxford: Archaeopress. 
Блажић, С. 1995. Остаци животињских врста са локалитета на траси ауто-пута кроз Срем, у Археолошка истраживања дуж ауто-пута кроз Срем, ур. 3. Вапа, 321-346. Нови Сад: Покрајински завод за заштиту споменика културе.

Блажић, С. и Радмановић, Д. 2011. Фауна касновинчанских станишта Црквине и Бележ. Колубара 5: 239-250.

Bogaard, A., Fraser, R., Heaton, T. H. E., Wallace, M., Vaiglova, P., Charles, M., Jones, G., Evershed, R. P., Styring, A.K., Andersen, N. H., Arbogast, R-M., Bartosiewicz, L., Gardeisen, A., Kanstrup, M., Maier, U., Marinova, E., Ninov, L., Schäfer, M. and Stephan, E. 2013. Crop manuring and intensive land management by Europe's first farmers. Proceedings of the National Academy of Sciences 110 (31): 12589-12594.

Bogaard, A. and Halstead, P. 2015. Subsistence practices and social routine in Neolithic southern Europe, in The Oxford Handbook of Neolithic Europe, eds. C. Fowler, J. Harding and D. Hofmann, 385-410. Oxford: Oxford University Press.

Bökönyi, S. 1986. Environmental and Cultural Effects on the Faunal Assemblages of Four Large Fourth Millennium B.C. Sites. A Béri Balough Ádám Múzeum Évkönyve 13: 69-88. Bökönyi, S. 1988. The Neolithic fauna of Divostin, in Divostin and the Neolithic of Central Serbia, eds. A. McPherron and D. Srejović, 419-445. Ethnology Monographs 10. Pittsburg: University of Pittsburg.

Borić, D. 2009. Absolute dating of metallurgical innovations in the Vinča Culture of the Balkans, in Metals and Societies. Studies in honour of Barbara S. Ottaway, eds. T.K. Kienlin and B.W. Roberts, 191-245. Bonn: Habelt.

Borić, D. 2015. The End of the Vinča World: Modelling the Neolithic to Copper Age Transition and the Notion of Archaeological Culture, in Neolithic and Copper Age Between the Carpathians and the Aegean Sea: Chronologies and Technologies from the 6th to the 4th Millennium BCE, eds. S. Hansen, P. Raczky, A. Anders and A. Reingruber, 157-217. Bonn: Habelt.

Bulatović, A. and Vander Linden, M. 2017. Absolute Dating of Copper and Early Bronze Age Levels at the Eponymous Archaeological Site Bubanj (Southeastern Serbia). Radiocarbon 59 (4): 1047-1065.

Bulatović, A. and Milanović, D. 2020. Bubanj, the Eneolithic and the Early Bronze Age tell in southeastern Serbia. MPK series 90. Vienna: Austrian Academy of Sciences Press. Bulatović, A., Gori, M. and Vander Linden, M. 2020. Radiocarbon Dating the 3rd Millennium BC in the Central Balkans: a re-examination of the Early Bronze Age sequence. Radiocarbon. https://doi.org/10.1017/RDC.2020.61

Bulatović, J. 2010. Ostaci faune iz zatvorenih eneolitskih celina na nalazištu Bubanj kod Niša. Unpublished master thesis, University of Belgrade.

Bulatović, J. 2018. Arheozoološki aspekti društvenih i kulturnih promena na centralnom Balkanu u $V$ milenijumu pre nove ere. Unpublished doctoral dissertation. University of Belgrade.

Bulatović, J. 2020. Preliminary Report on Animal Bones from Bubanj, in Bubanj, the Eneolithic and the Early Bronze Age tell in southeastern Serbia, eds. A. Bulatović and D. Milanović, 329-337. MPK series 90. Vienna: Austrian Academy of Sciences Press. 
Булатовић, J. и Милошевић, С. 2015. Животињски остаци из поткапине Мокрањске стене, у Мокрањске стене: културно наслеђе Неготинске крајине, eds. А. Капуран и А. Булатовић, 41-55. Неготин: Музеј Крајине.

Bulatović, J. and Orton, D. in press. Animal remains from the site of Pločnik, in The Rise of Metallurgy in Eurasia: The Archaeology of Early Metallurgy and Society in the Central Balkans, eds. M. Radivojević, B.W. Roberts, J. Kuzmanović-Cvetković, M. Marić, D. Šljivar and T. Rehren. Oxford: Archaeopress.

Булатовић, Ј. и Филиповић, Д. in press. Преглед археозоолошких и археоботаничких података са енеолитских налазишта у Србији, in Бубањ, праисторијско насеље и некропола из Новог века, eds. А. Булатовић, Д. Милановић и Т. Трајковић-Филиповић. Ниш: Народни музеј - Београд: Археолошки институт..

Chapman, J. 1982. 'The Secondary Products Revolution' and the Limitations of the Neolithic. Bulletin of the Institute of Archaeology London 19: 107-122.

Chapman, J. 1990. The Neolithic in the Morava-Danube confluence area: a regional assessment of settlement pattern, in Selevac: a Neolithic Village in Yugoslavia, eds. R. Tringham and D. Krstić, 13-43. Monumenta archaeologica 15. Los Angeles: University of California. Dimitrijević, V. 2008. Vertebrate fauna of Vinča - Belo Brdo (excavation campaigns 1998-2003). Старинар 56: 245-269.

Forenbaher, S. 1994. The Late Copper Age Architecture at Vučedol (Croatia). Journal of Field Archaeology 21: 307-323.

Filipović, D. 2014. Southwest Asian founder- and other crops at Neolithic sites in Serbia. Bulgarian e-Journal of Archaeology 4: 195-215.

Филиповић, Д. 2015. Археоботанички налази из средњеенеолитског (Бубањ - Салкуца) хоризонта локалитета Мокрањске стене - поткапина у североисточној Србији, in Мокрағске стене: културно наслеђе Неготинске крајине, eds. А. Капуран и А. Булатовић, 57-69. Неготин: Музеј Крајине.

Filipović, D. 2020. A Glimpse of Eneolithic Plant Economy at the Site of Bubanj in Serbia, in Bubanj, the Eneolithic and the Early Bronze Age tell in southeastern Serbia, eds. A. Bulatović and D. Milanović, 339-307. MPK series 90. Vienna: Austrian Academy of Sciences Press.

Filipović, D. and Obradović, Đ. 2013. Archaeobotany at Neolithic Sites in Serbia: A Critical Overview of the Methods and Results, in Bioarheologija na Balkanu: bilans $i$ perspektive, eds. N. Miladinović-Radmilović and S. Vitezović, 25-55. Beograd: Srpsko arheološko društvo.

Filipović, D., Meadows, J., Dal Corso, M., Kirleis, W., Alsleben, A., Akeret, Ö., Bittmann, F., Bosi, G., Ciută, B., Dreslerová, D., Effenberger, H., Gyulai, F., Heiss, A.G., Hellmund M., Jahns, S., Jakobitsch, Th., Kapcia, M., Klooß, S., Kohler-Schneider, M., Kroll, H., Makarowicz, P., Marinova, E., Märkle, T., Medović, A., Mercuri, A.M., Mueller-Bieniek, A., Nisbet, R., Pashkevich, G., Perego, R., Pokorný, P., Pospieszny, L., Przybyla, M., Reed, K., Rennwanz, J., Stika, H.-P., Stobbe, A., Tolar, T., Wasylikowa, K., Wiethold, J., Zerl, T. 2020. New AMS ${ }^{14} \mathrm{C}$ dates track the arrival and spread of broomcorn millet cultivation and agricultural change in prehistoric Europe. Scientific Reports 10:13698. 
Filipović, D. in press a. Plant use at Neolithic-Early Chalcolithic Belovode, in The Rise of Metallurgy in Eurasia: The Archaeology of Early Metallurgy and Society in the Central Balkans, eds. M. Radivojević, B.W. Roberts, J. Kuzmanović-Cvetković, M. Marić, D. Šljivar and T. Rehren. Oxford: Archaeopress.

Filipović, D. in press b. Archaeobotanical analysis of the Neolithic-Early Chalcolithic site of Pločnik, in The Rise of Metallurgy in Eurasia: The Archaeology of Early Metallurgy and Society in the Central Balkans, eds. M. Radivojević, B.W. Roberts, J. KuzmanovićCvetković, M. Marić, D. Šljivar and T. Rehren. Oxford: Archaeopress.

Gaastra, J., de Vareilles, A. and Vander Linden, M. 2019. Bones and Seeds: An Integrated Approach to Understanding the Spread of Farming across the Western Balkans. Environmental Archaeology. DOI: 10.1080/14614103.2019.1578016

Гарашанин, М. 1973. Праисторија Србије. Београд: Српска књижевна задруга.

Greenfield, H. 1986. The Paleoeconomy of the Central Balkans (Serbia). A Zooarchaeological Perspective on the Late Neolithic and Bronze Age (ca. 4500-1000 B.C.). Oxford: Archaeopress. Greenfield, H. 1991. Fauna from the Late Neolithic of the Central Balkans: issues in subsistence and land use. Journal of Field Archaeology 18: 161-186.

Greenfield, H. J. 1999. The advent of transhumant pastoralism in the temperate southeast Europe: a zooarchaeological perspective from the Central Balkans, in Transhumant Pastoralism in Southern Europe: Recent Perspectives from Archaeology, History and Ethnology, eds. L. Bartosiewicz and H.J. Greenfield, 15-36. Budapest: Archaeolingua.

Greenfield, H. 2014. The origins of secondary product exploitation and the zooarchaeology of the Late Neolithic, Eneolithic, and Middle Bronze Age at Vinča-Belo Brdo, Serbia: the 1982 excavations, in Animal Secondary Products. Domestic Animal Exploitation in Prehistoric Europe, the Near East and the Far East, ed. H. Greenfield, 274-334. Oxford: Oxbow Books.

Gyulai, F. 2010. Archaeobotany in Hungary. Seed, Fruit, Food and Beverage Remains in the Carpathian Basin: an Archaeobotanical Investigation of Plant Cultivation and Ecology from the Neolithic to the late Middle Ages. Budapest: Archaeolingua.

Halstead, P. 1987. Traditional and Ancient Rural Economy in Mediterranean Europe: plus ça change? Journal of Hellenic Studies 107: 77-87.

Halstead, P. 2000. Land use in postglacial Greece: cultural causes and environmental effects, in Landscape and Land Use in Postglacial Greece, eds. P. Halstead and C. Frederick, 110-128. Sheffield: Sheffield Academic Press.

Halstead, P. 2006. Sheep in the garden: the integration of crop and livestock husbandry in early farming regimes of Greece and Southern Europe, in Animals in the Neolithic of Britain and Europe, eds. D. Serjeantson and D. Field, 42-55. Oxford: Oxbow.

Kapuran, A. and Milošević, S. 2013. Rockshelter Mokranjske Stene - a New Late Prehistoric Site in Eastern Serbia region. Archaeologia Bulgarica XVII(2): 17-37.

Kapuran, A., Bulatović, A. and Milanović, D. 2018. Settlement pattern changes during the Central Balkans Copper Age, in Communities in Transition: The Circum-Aegean Area During the 5th and 4th Millennia BC, eds. S. Dietz, F., Mavridis, Ž. Tankosić and T. Takaoğlu, 77-88. Oxford: Oxbow. 
Лазић, М. 1992. Допринос археозоологије у проучавању економије праисторијских друштвених заједница, in Археологија и природне науке, ed. Д. Срејовић, 49-60. Београд: Српска академија наука и уметности.

Legge, A. 1990. Animals, economy and environment, in, in Selevac: a Neolithic Village in Yugoslavia, eds. R. Tringham and D. Krstić, 215-242. Monumenta archaeologica 15. Los Angeles: University of California.

Link, T. 2009. Das Ende der spätneolithischen Tellsiedlungen im Karpatenbecken - der Beginn einer mobileren Lebensweise? in Varia neolithica V, Mobilität, Migration und Kommunikation in Europa während des Neolithikums und der Bronzezeit. Beiträge zur Ur- und Frühgeschichte Mitteleuropas 53: 95-101.

Милановић, Д. 2017. Централни Балкан у 5. миленијуму пре н.е.: обрасии насељавања и друштвено-економске промене. Unpublished doctoral dissertation. University of Belgrade.

Милановић, Д. и Трајковић-Филиповић, Т. 2015. Стара ископавања на локалитету Бубањ. Ниш: Народни музеј Ниш.

Обрадовић, Ђ. 2020. Археоботаничка истраживања у касном неолиту Поморавља: друштвени и економски аспекти производње и припреме хране. Unpublished doctoral dissertation. University of Belgrade.

Orton, D. 2008. Beyond Hunting and Herding: Humans, animals and the political economy of the Vinča period. Unpublished doctoral dissertation, University of Cambridge, UK. Orton, D. 2012. Herding, Settlement, and Chronology in the Balkan Neolithic. European Journal of Archaeology 15 (1): 5-40.

Orton, D., Gaastra, J. and Vander Linden, M. 2016. Between the Danube and the Deep Blue Sea: Zooarchaeological Meta-Analysis Reveals Variability in the Spread and Development of Neolithic Famring across the Western Balkans. Open Quaternary 2(6): 1-26.

Orton, D., Bulatović, J. and Stojanović, I. in press. Evidence for animal use in the central Balkan Neolithic across the early metallurgical horizon: the animal remains from Belovode and Pločnik in context, in The Rise of Metallurgy in Eurasia: The Archaeology of Early Metallurgy and Society in the Central Balkans, eds. M. Radivojević, B.W. Roberts, J. Kuzmanović-Cvetković, M. Marić, D. Šljivar and T. Rehren. Oxford: Archaeopress.

Parkinson, W. A. 2006. Tribal boundaries: stylistic variability and social boundary maintenance during the transition to the Copper Age on the Great Hungarian Plain. Journal of Anthropological Archaeology 25: 33-58.

Parkinson, W. A., Yerkes, R.W. and Gyucha, A. 2004. The Transition from the Neolithic to the Copper Age: Excavations at Vésztö-Bikeri, Hungary, 2000-2002. Journal of Field Archaeology 29: 101-121.

Radivojević, M., Roberts, B. W., Kuzmanović-Cvetković, J., Marić, M., Šljivar, D. and Rehren, T. (in prep.) The Rise of Metallurgy in Eurasia: The Archaeology of Early Metallurgy and Society in the Balkans. Oxford: Archaeopress.

Reed, K. 2017. Agricultural change in Copper Age Croatia (ca. 4500-2500 cal B.C.)? Archaeological and Anthropological Sciences 9: 1745-1765. 
Russell, N. 1993. Hunting, Herding and Feasting: human use of animals in Neolithic Southeast Europe. Unpublished doctoral dissertation, University of California at Berkeley. Šarić, J. 2020. Chipped Stone Artefacts from the Bubanj Site - Excavations from Seasons 2008, 2009, 2012 and 2014, in Bubanj, the Eneolithic and the Early Bronze Age tell in southeastern Serbia, eds. A. Bulatović and D. Milanović, 388-418. MPK series 90. Vienna: Austrian Academy of Sciences Press.

Sherratt, A. 1981. Plough and pastoralism: aspects of the secondary products revolution, in Pattern of the Past, eds. I. Hodder, G. Isaac and N. Hammond, 261-301. Cambridge: Cambridge University Press.

Sherratt, A. 1993. The secondary products revolution of animals in the Old World. World Archaeology 15: 90-104.

Spasić, M. 2012. Cattle to settle - bull to rule: on bovine iconography among Late Neolithic Vinča communities. Documenta Praehistorica 39: 295-308.

Стојановић, И. и Булатовић, Ј. 2013. Археозоолошка истраживања млађе праисторије на територији Србије, in Bioarheologija na Balkanu: bilans i perspektive, eds. N. Miladinović-Radmilović i S. Vitezović, 13-24. Beograd: Srpsko arheološko društvo.

Stojanović, I. and Orton, D. in press. Animal remains from the site of Belovode, in The Rise of Metallurgy in Eurasia: The Archaeology of Early Metallurgy and Society in the Central Balkans, eds. M. Radivojević, B.W. Roberts, J. Kuzmanović-Cvetković, M. Marić, D. Šljivar and T. Rehren. Oxford: Archaeopress.

Tasić, N. 1995. Eneolithic cultures of the central and western Balkans. Beograd: Balkanološki Institut.

Tasić, N., Marić, M., Penezić, K., Filipović, D., Borojević, K., Borić, D., Reimer, P., Russell, N., Bayliss, A., Barclay, A., Gaydarska, B. and Whittle, A. 2015. The end of the affair: formal chronological modelling for the top of the Neolithic tell of Vinča - Belo Brdo. Antiquity 89: 1064-1082.

Томић, Е. 1988. Енеолитско насеље на локалитету Јазбина у Макрешанима, in $P a$ шка баштина, eds. С. Ђорђевић, 179-186. Краљево: Завод за заштиту споменика културе.

Tringham, R. 1992. Life after Selevac: Why and how a Neolithic settlement is abandoned. Balcanica 23: 133-145.

Tringham, R. and Krstić, D. 1990. Conclusion: Selevac in the Wider Context, in Selevac: a Neolithic Village in Yugoslavia, eds. R. Tringham and D. Krstić, 567-616. Monumenta archaeologica v. 15. Los Angeles: University of California.

Трипковић, Б., Церовић, М., Филиповић, Д., Трипковић, А. и Живаљевић, И. 2017. Шанац-Изба код Липолиста, локалитет типа “Обровац”: стратиграфија и релативна хронологија. Гласник Српског археолошког друштва 33: 47-71.

Vander Linden, M. and Bulatović, A. 2020. Bubanj: The Absolute Chronology, in Bubanj, the Eneolithic and the Early Bronze Age tell in southeastern Serbia, eds. A. Bulatović and D. Milanović, 239-244. MPK series 90. Vienna: Austrian Academy of Sciences Press. 
van Zeist, W. 2002. Plant Husbandary and Vegetation of Tell Gomolava, Vojvodina, Yugoslavia, Palaeohistoria 43/44: 87-115.

Vuković, S. and Marković, D. 2019. Animal remains from the late prehistoric horizons from the sites Nad Klepečkom and Rit, in Viminacium in Prehistory - Excavations 2005 -2015, eds. A. Kapuran, A. Bulatović, S. Golubović and V. Filipović, 224-248. Belgrade: Institute of Archaeology.

Weinstein, M. 2007. Understanding the Transition from the Late Neolithic to the Early Copper Age Using Faunal Analysis from Two Balkan Region Early Copper Age Sites: Vésztő-Bikeri and Körösladány-Bikeri, Hungary. Journal of Young Investigators 2007. (Available online at https://www.jyi.org/2007-november/2007/11/10/understanding-thetransition-from-the-late-neolithic-to-the-early-copper-age-using-faunal-analysis-fromtwo-balkan-region-early-copper-age-sites-veszt-bikeri-and-krsladany-bikeri-hungary).

Зотовић, М. 1988. Основе енеолитског развоја у југозападној Србији. Ужички зборник 17: 57-78. 


\section{Драгана Филиповић}

Институт за праисторију и протоисторију, Универзитет у Килу, Немачка Јелена Булатовић

Лабораторија за биоархеологију, Филозофски факултет, Београд Александар Булатовић

Археолошки институт, Београд

\section{ПРОИЗВОДНА ХРАНЕ ТОКОМ И ПОСЛЕ НЕОЛИТСКО- ЕНЕОЛИТСКЕ ТРАНЗИЦИЈЕ НА ЦЕНТРАЛНОМ БАЛКАНУ: ШИРИ КОНТЕКСТ НАЛАЗА ДОМАЋИХ БИЛАКА И ЖИВОТИЫА СА ЕНЕОЛИТСКОГ БУБЫА У ЈУЖНОЈ СРБИЈИ}

Кључне речи: цчентрални Балкан (Србија), касни неолит, енеолит, ратарство, сточарство, друштвено-економска промена

Друга половина 5. и већи део 4. миленијума пре нове ере на централном Балкану означава се као период прелаза из касног неолита (тј. винчанске културе) у рани енеолит, и енеолитски период. На основу значајних промена у обрасцима насељавања и величини насеља, у погребној пракси и у материјалној култури, сматра се да је током прелазног периода дошло до развоја нових образаца у друштвеним односима и организацији, у економији и производњи и у идеологији поствинчанских заједница, које су, за разлику од претходних великих, дуготрајних насеља, почеле да оснивају мање, релативно краткотрајне насеобине, углавном на претходно ненасељеним локацијама. Различити фактори су предложени као покретачи ових трансформација - друштвени сукоби, инвазије са стране, климатске промене, те пад расположивих природних ресурса и недовољно хране. За разматрање евентуалних климатских промена током енеолита не постоје никакви подаци, а доскора се веома мало знало и о економији заснованој на биљкама и животињама у постнеолитском периоду.

Најјасније формулисан закључак о узроцима распада каснонеолитског друштва, који налази и највише потпоре у археолошким сазнањима, јесте тај да су винчанске заједнице достигле границе одрживости заједничког живота (у социолошком смислу), што је довело до „фисије” и фрагментације великих заједница на мање групе. Сличан модел каснонеолитско-раноенеолитских друштвених промена предложен је и за Карпатски басен - „попуштање" друштвене кохезије као одговор на могуће друштвене тензије. Поред промена и нових трендова које наступају почетком и током енеолита на 
централном Балкану, приметан је и висок степен сличности/континуитета у појединим аспектима живота; на пример, поред мањих, развијају се и велика, дуготрајна енеолитска насеља, попут оних на локалитетима Бубањ и Велика Хумска Чука у јужној Србији. Док су ови и други аспекти енеолитских заједница у извесној мери познати и истражени, производња хране је доскора била велика непознаница. До сада је пак зооархеолошки и археоботанички истражено неколико енеолитских локалитета, а нова ископавања на Бубњу донела су важне податке о узгајању и употреби домаћих биљака и животиња. Иако су подаци и даље скромни, посебно они о пољопривредним активностима, сада је ипак могућ увид у поједине аспекте производње хране.

У овом раду смо до сада прикупљене зооархеолошке и археоботаничке податке са Бубња размотрили у ширем географском и хронолошком контексту тако што смо упоредили сазнања о узгајању и употреби животиња и биљака са до сада анализираних каснонеолитских и енеолитских налазишта на територији Србије. Упоредна анализа показала је да су исте врсте домаћих животиња - говеда, овце/козе и свиње - гајене и у неолиту и у енеолиту. С друге стране, остаци оваца и коза и свиња су, спрам говечета, заступљенији у узорцима са енеолитских налазишта. Утисак је, стога, да је значај оваца и коза, као и свиња, био већи у енеолиту, што је важна разлика у односу на касни неолит, током ког је говече било доминантно. Постоje, међутим, и изузеци од овог општег запажања; на пример, на налазишту Винча - Бело брдо, релативни однос економски најзначајних домаћих животиња је мање-више исти током оба периода. Такође, на касноенеолитском налазишту Кудош-Шашинци, већина остатака припада домаћем говечету. Прелиминарни закључак је да генерално уједначена слика карактеристична за касни неолит постаје разноврснија током енеолита и јављају се јасне регионалне и хронолошке разлике у погледу значаја домаћих животиња.

Археоботанички подаци показују да се спектар гајених врста на налазиштима касног неолита и енеолита у Србији увелико преклапа, те да основне културе познате из неолита - једнозрна и двозрна пшеница - остају основ пољопривредне производње и током енеолита. И овде се, међутим, као и код домаћих животиња, уочавају могуће разлике између локалитета. Рецимо, у касноенеолитском слоју Гомолаве забележена је већа количина јечма, што је за сада једини случај како за неолит тако и за енеолит, јер се јечам на другим анализираним локалитетима из ових периода јавља само у траговима. Подаци са Бубња указују на могући раст у важности махунарки, тачније сочива, од раног ка касном енеолиту, те мање значајну улогу двозрне пшенице кроз време, али је број остатака изузетно мали за чврсте закључке. 
Док релативно непромењен избор гајених врста кроз касни неолит и енеолит истиче континуитет, донекле су видљиве потенцијалне разлике између локалитета у степену производње појединих пољопривредних култура. Могуће је да долази до промене у методама и интензитету земљорадње, а врло вероватно у вези са променама у сточарству, рецимо у погледу потребе за производњом сточне хране или варијацијама у величини површина под усевима или оним намењеним за испашу. Увид у ове и сличне аспекте производње хране у енеолиту захтева знатно већу количину података од оне која је сада на располагању. 